\title{
Kajian Sistem Pengolahan Pisang Sale dengan Menggunakan Gas Elpiji
}

\section{Nazaruddin*}

\section{A R T I C L E I N F O}

Article history:

Received 20 November 2017

Received in revised form

11 Desember 2017

Accepted 13 Januari 2018

Available online 25

Februari 2018

\section{Kata Kunci:}

Pengeringan, Kadar

air,Temperatur

Keywords:

Drying, Water content

Temperature

\begin{abstract}
A B S T R A K
Pisang sale merupakan makanan tradisional yang sangat digemari di kalangan masyarakat Aceh, khusus nya produksi pisang sale yang terbanyak berasal dari daerah Aceh utara dan Aceh timur. Proses pengolahan pisang sale tradisional dengan menggunakan metode pengasapan dengan menggunakan bahan bakar kayu dan tempurung kelapa. Pisang sale tradisional warnanya coklat kehitaman dan rasanya kurang enak. Proses pengolahan pisang sale disini menggunakan lemari pengering dengan metode pemanasan dengan suhu rata-rata pada pengujian ini $90-70^{\circ} \mathrm{C}$ selama 14 jam.Tujuan penelitian untuk mendapatkan temperatur yang optimal yang digunakan dalam proses pengolahan pisang sale supaya mengetahui mutu dan kualitas yang baik dari pada dengan cara tradisional. Proses pemanasan awal dengan temperatur tinggi untuk mempercepat penurunan kadar air dalam pisang sehingga proses pengeringan lebih cepat.Kualitas pisang sale yang dihasilkan dengan warna kemerahmerahan dan rasa nya manis karena glukosa di dalam pisang. Kemudian bahan bakar yang digunakan adalah gas elpiji.Manfaat dari menggunakan gas elpiji ini sendiri adalah karena ramah lingkungan, tidak menyebabkan polusi udara dan hasil pembakaran elpiji tidak meninggalkan bau, sehingga cocok untuk digunakan sebagai bahan bakar ataupun bahan baku untuk industri.
\end{abstract}

\section{A B S T R A C T}

Bananas sale or pisang sale is a popular traditional food in Aceh and its production mostly comes from the area of northern Aceh and east Aceh. Traditional banana processing process is using fumigation method by wood fuel and coconut shell. Traditional banana sale is dark brown and tastes is less good. The banana processing process here uses a heating cabinet with a heating method and with an average temperature of $90-70^{\circ} \mathrm{C}$ for 14 hours. The purpose of the study was to obtain the optimal temperature used in the processing of banana sale in order to know the quality and good quality of on the traditional way. The preheating process with high temperature is to accelerate the decrease in water content in bananas so that the drying process becomes faster. The quality of banana sale is produced with a reddish color and very sweet because of glucose in the banana. The cooking process is by using LPG gas. The benefits of using LPG gas are because it is environmentally friendly, does not cause air pollution and the result of LPG combustion does not leave the smell, so it is suitable for use as fuel or raw materials for industry.

\footnotetext{
* Corresponding author.

E-mail addresses: nazaruddinsimpo@gmail.com (Nazaruddin)
} 


\section{Pendahuluan}

Provinsi Aceh secara topografi merupakan daerah yang memiliki tanaman pisang yang tergolong cukup untuk kebutuhan. produksi pisang di Aceh yang di hasilkan mencapai 69 ribu ton per tahunnya. Khususnya di daerah Banda Aceh mencapai 101 ton per tahunnya (Badan Pusat Statistik, 2012). Pada saat panen raya, produksi pisang melebihi kebutuhan sehingga tidak termanfaatkan dan terbuang percuma sehingga merugikan petani dan masyarakat. Untuk itu diperlukan suatu pemikiran bagaimana cara mengolah pisang tersebut menjadi makanan yang awet dan enak di makan sehingga nantinya mempertinggi nilai tambah pisang dengan cara pengeringan pisang, atau di kenal masyarakat dengan sebutan pisang sale.

Pisang sale merupakan makanan tradisional yang cukup potensial di kalangan masyarakat Aceh, produksi pisang sale yang terbanyak berasal dari daerah Aceh utara, Pantonlabu dan Aceh timur, Simpang ulim. Khusus di daerah Banda Aceh produksi pisang sale tidak ada, karena biasanya masyarakat di sini membelinya langsung di sana dengan harga yang terjangkau.

Proses pengolahan pisang sale di daerah Aceh utara dengan cara tradisional dengan meletakkan pisang di tempat pemangangan kemudian menggunakan bahan bakar kayu atau tempurung kelapa. Pisang sale ini sendiri memiliki kekurangan serta membutuhkan waktu yang lama dalam proses pembuatannya. misalnya dari segi kualitas pisang sale nya tingkat kematangan tidak merata, berwarna coklat sampai kehitaman dengan aroma yang tidak enak karena proses dibuatnya dengan cara pengasapan. Dan dari segi kesehatan pisang sale ini tidak higienis karena proses cara pembuatan tersebut langsung terkontaminasi dengan asap sehingga bagi masyarakat yang banyak mengkonsumsinya kurang baik untuk kesehatan.

Maka disini proses pengolahannya tidak menggunakan lagi proses pengasapan melainkan menggunakan lemari pengering sebagai alat pemanas dan pengeringan, dengan pendistribusian temperatur yang telah disesuaikan dan kemudian waktu yang digunakan lebih sedikit dibandingkan dengan cara tradisional. Disini bahan bakar yang digunakan adalah gas elpiji. Manfaat dari menggunakan gas elpiji ini sendiri karena ramah lingkungan dan tidak menyebabkan polusi.

\section{Metode}

Penelitian ini direncanakan di Fakultas Teknik Universitas Iskandarmuda. Sedangkan waktu penelitian ini, dimulai dari studi literatur, studi lapangan, persiapan alat, penulisan proposal Tugas Akhir, sampai seminar proposal tugas akhir yang memerlukan waktu lebih kurang 6 (Enam) bulan. Peralatan pengering terbagi beberapa bagian yaitu:

1. Ruang bakar

Ruang bakar yang berfungsi sebagai tempat pembakaran bahan bakar sebagai sumber gas panas. Disini bahan bakar yang digunakan adalah gas elpiji

2. Sudut pengarah

Sudut pengarah yang berfungsi sebagai pengarah gas panas hasil pembakaran bahan bakar untuk masuk keruang pengering.

3. Ruang pengering

Ruang pengering yang berfungsi sebagai tempat meletakan bahan (pisang) selama proses pengeringan berlangsung. Dalam ruang pengering juga terdapat saluran udara panas yang berfungsi sebagai penyalur gas panas yang letaknya bersisian dengan ruang pengering dari ruang bakar hingga bagian atas ruang pengering.

4. Rak pengering

Rak pengering yang berfungsi sebagai tempat meletakan bahan (pisang) yang akan di kering kan.

5. Cerobong asap

Cerobong asap yang berfungsi sebagai saluran pembuangan gas asap hasil pembakaran bahan bakar. 


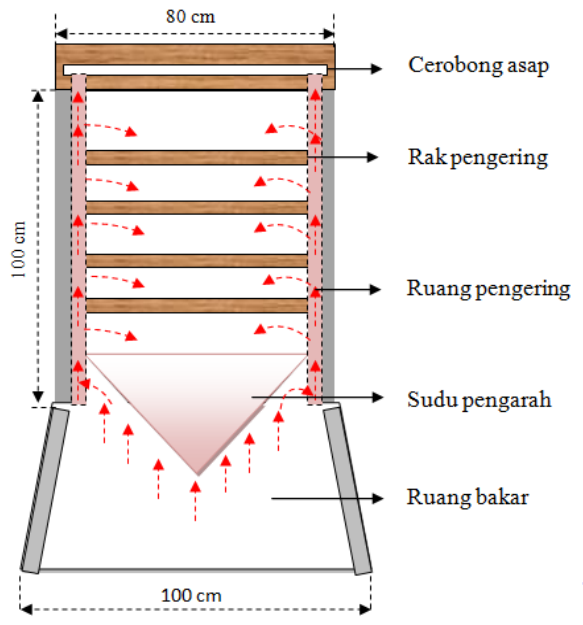

Gambar 1. Mekanismealiranudaradalamruangpengering

Alat ukur yang digunakan yaitu: termometer digital, stopwatch dan timbangan digital. Bahan yang dikeringkan adalah pisang wak (Musa acuminate). Adapun Tata cara pengujian yaitu: 1. Menyiapkan pisang yang sudah dikupas dan dibersihkan, 2. Menyiapkan bahan bakar gas elpiji, 3. Menyiapkan lemari pengering, 4. Memasang alat ukur pada ruang pengering, 5. Memanaskan ruang pengering dengan bahan bakar gas elpiji yang telah disiapkan hingga temperatur yang telah direncanakan yaitu $70-75^{\circ} \mathrm{C}$ dengan waktu $14-15 \mathrm{jam}, 80-85^{\circ} \mathrm{C}$ dengan waktu $12-13$ jam dan $90-95^{\circ} \mathrm{C}$ dengan waktu $10-11$ jam, 6 . Sebelum dimasukan kedalam ruang pengering, pisang ditimbang terlebih dahulu massanya, 7. Pembacaan suhu pada thermometer digital dilakukan setiap 1 jam sekali sampai batas waktu ditentukan.Kemudian pisang yang telah mengalami proses pengeringan ditimbang kembali untuk mengetahui jumlah kadar air yang berkurang.

\section{Hasil dan pembahasan}

\section{Distribusi temperatur di dalam ruang pengering}

Distribusi temperatur di dalam ruang pengering dengan sampel I , II dan III dengan menggunakan 2 rak dengan suhu rata-ratanya adalah $70-92^{\circ} \mathrm{C}$ selama 14 jam (08.00-22.00) untuk proses pengeringan. Dalam grafik dapat dilihat proses perubahan pemanasan awal dengan temperatur tinggi yang kemudian suhu nya diturunkan secara bertahap sampai $70^{\circ} \mathrm{C}$. Di sini dapat dilihat pada tabel 1 pada lampiran, dan dapat diplotkan pada grafik berikut ini :

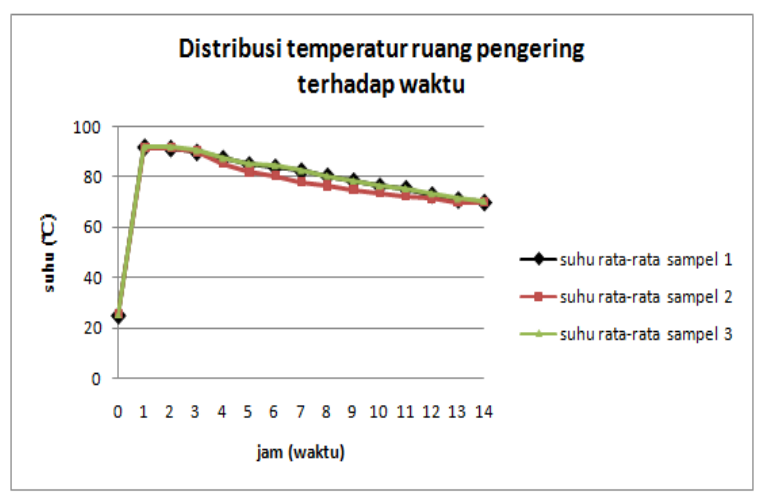

Gambar 2. Grafik distribusi temperatur di dalam ruang pengering

Dari grafik di atas dapat dilihat bahwa suhu awal di dalam ruang pengering adalah $26^{\circ} \mathrm{C}$ saat pemanas belum dinyalakan. Kemudian tungku dinyalakan dan ditunggu hingga temperature dalam ruang pengering rata-rata $90-92^{\circ} \mathrm{C}$, dilanjutkan hingga waktu 3-4 jam. Hal ini dilakukan supaya kadar air di dalam bahan cepat berkurang. Selanjutnya suhu $90-92^{\circ} \mathrm{C}$ diturunkan bertahap sekitar sampai $89-75^{\circ} \mathrm{C}$ dalam waktu 5-10 jam karena kadar air tinggal sedikit karena sudah banyak terbuang pada proses 
pemanasan awal. Kemudian suhu diturunkan lagi sampai $75-70^{\circ} \mathrm{C}$ karena kadar air jauh berkurang dan tinggal glukosa di dalam pisang. Menurut Bakker Arkema (1992), pengeringan yang baik adalahdengan pemanasan awal suhu rendah kemudian dinaikkan bertahap menjadi suhu tinggi supaya tidak merusak struktur bahan. Tetapi di sini pemanasan awal harus suhu tinggi kemudian diturunkan secara bertahap suhunya supaya kadar air di dalam bahan cepat berkurang dan proses pengeringan lebih cepat. Di sini dapat dilihat bahwa suhu rata-rata ruang pengering pada sampel I, II dan III adalah seragam. Ini bisa dilihat pada pembacaan termometer di dalam ruang pengering yang membuktikan bahwa suhu di dalam ruang pengering antara rak 1 dan rak 2 untuk semua sampel tidak berubah.

\section{Laju penurunan kadar air}

Laju penurunan kadar air terhadap waktu pada sampel I dengan massa 900 gr, sampel II dengan massa 560 gr dan sampel III dengan massa 410 gr. Penurunan kadar air di setiap sampel dan di setiap jam berbeda-beda karena di pengaruhi dari temperatur. Di sini dapat dilihat pada tabel 1 pada lampiran, dapat diplotkan pada grafik berikut ini:

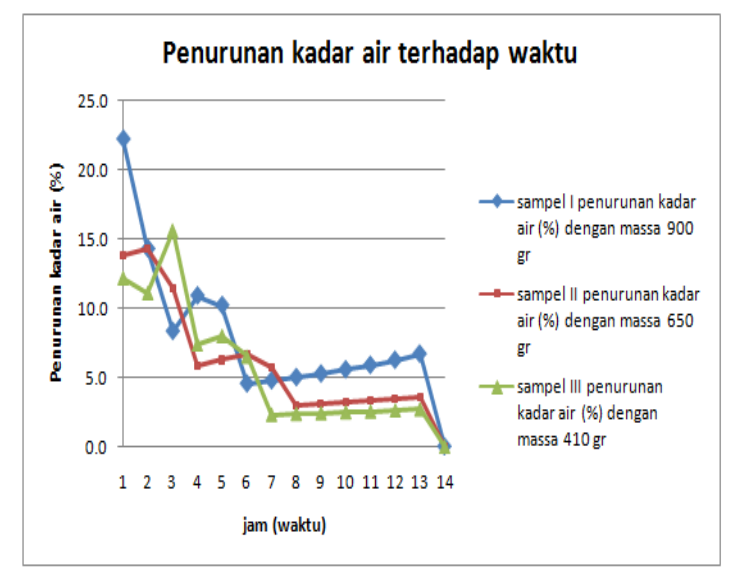

Gambar 3. Grafik laju penurunan kadar air terhadap waktu

Dari grafik di atas telah dihitung bahwa persentase laju penurunan kadar air pada temperatur 90 $92^{\circ} \mathrm{C}$ lebih besar berkurang nya karena pada pemanasan awal suhunya nya tinggi dengan waktu 3-4 jam. Selanjutnya suhu diturunkan secara bertahap $89-75^{\circ} \mathrm{C}$ selama 5-10 jam. Di sini presentase penurunan kadar air berkurang nya lebih sedikit karena sisa kadar air sudah banyak berkurang karena sudahterjadi pemanasan awal yang tinggi. Selanjutnya pada suhu $75-70^{\circ} \mathrm{Cpemanasan}$ dengan berubahnya warna pisang menjadi merah karena glukosa di dalam pisang dan kadar air sudah habis.

\section{Laju penurunan massa}

Laju penurunan massa terhadap waktu dengan sampel I dengan massa $900 \mathrm{gr}$, sampel II dengan massa 650 gr dan sampel III dengan massa 410 gr. Massa bahan akan mengalami penurunan cepat disebabkan oleh suhu di dalam ruang pengering yang tinggi. Sehingga dalam proses pengeringan membutuhkan waktu yang singkat.

Pada pengujian ini suhu awal di dalam ruang pengering $26^{\circ} \mathrm{C}$ karena belum terjadinya pemanasan sehingga massa awal sampel pisang I dengan massa 900 gr, sampel pisang II dengan massa 650 gr dan sampel pisang III dengan massa 410 gr. Selanjutnya di lakukan pemanasan awal dengan suhu $90-92^{\circ} \mathrm{C}$ selama 3-4 jam. Massa penurunan sampel pisang lebih cepat terbuang dari massa awalnya. Ini disebabkan terjadinya pemanasan awal suhu tinggi sehingga massa sampel lebih pisang cepat turun dalam waktu singkat, Selanjutnya suhu tinggi diturunkan secara perlahan-lahan karena kadar air di dalam bahan sudah banyak terbuang dan temperatur nya $89-75^{\circ} \mathrm{C}$ selama 5-10 jam. Selanjutnya suhu diturunkan lagi sekitar $75-70^{\circ} \mathrm{C}$ selama 4 jam. selanjutnya cara menghitung massa bahan ditimbang terlebih dahulu tiap jam nya, 
kemudian ditimbang lagi sampai massa sampel pisang tidak turun lagi. Kemudian melihat tampilan pisang sudah sesuai apa belum dari segi warna dan rasanya (Winarno, dkk. 1980.

\section{Hasil pengolahan pisang sale}

Berdasarkan penelitian yang telah dilakukan, maka didapatkan hasil pengolahan pisang sale pada pengujian di bawah ini dengan suhu rata-rata $90-70^{\circ} \mathrm{C}$

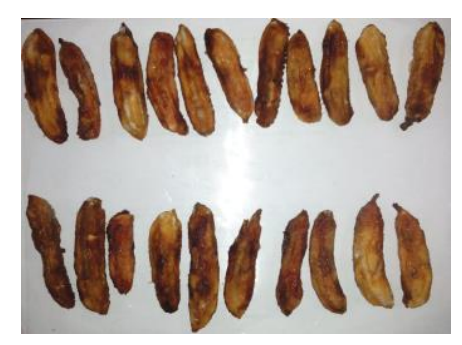

Gambar 4 pengujian padasampel I

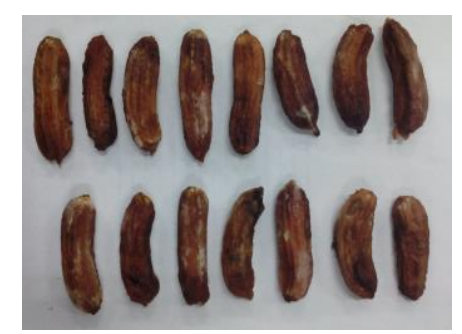

Gambar 5. Pengujianpadasampel II

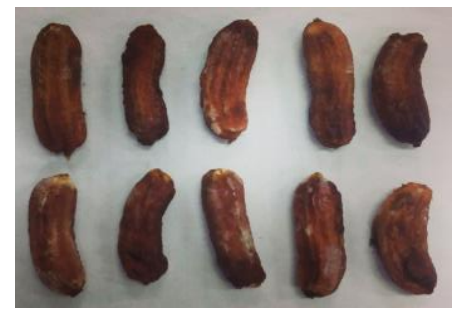

Gambar 6. Pengujianpadasampel III

\section{Analisa Ekonomi Teknik}

Adapunanalisaekonomiteknik yang didapatpadapengolahanpisang sale adalahsebagaiberikut:

Biaya investasi alat Rp. 10.000.000

Kebutuhan perhari:

Harga pisang per sisir Rp. 3000

Pisang yang dibutuhkan $300 \mathrm{sisir}=100 \mathrm{~kg}$

Rp. $3000 \times 300$

Rp. 900.000

Gas elpiji

Rp. 105.000

Gaji pekerja untuk 1 orang

Rp. $\quad 30.000$

Plastik ukuran $1 \mathrm{~kg}$

Rp. $\quad 8.000$

Transportasi per hari

Rp. $\quad 20.000$

Kebutuhan lain-lain

Rp. $\quad 50.000$

Total

Rp.1.113.000

Massa pisang sebelum proses pengeringan adalah $100 \mathrm{~kg}$. kemudian setelah mengalami proses pengeringan adalah $50 \mathrm{~kg}$. 
harga pisang sale yang dijual dipasaran Rp. 35.000

jadi, hasil pengeringan $x$ biaya perkilo yang dijual

$50 \times$ Rp. $40.000=$ Rp. 2.000 .000

Jadi, $1 \mathrm{x}$ produksi pisang sale selama 1 hari adalah Rp. 2.000.000

Kemudian. $1 \mathrm{x}$ produksi pisang sale - kebutuhan perhari

$=\mathrm{Rp}, 2.000 .000-\mathrm{Rp} .1 .113 .000=\mathrm{Rp} .887 .000$

Untuk 1 bulan, 26 hari yang aktif bekerja

$=26 \times \mathrm{Rp} .887 .000$

$=$ Rp. 23.062.000 per bulan

Jadi, biaya per bulan - biaya investasi alat

$=$ Rp. $23.062 .000-$ Rp. 10.000 .000

$=$ Rp. 13.062 .000

\section{Simpulan dan saran}

Setelah dilakukan penelitian dan pembahasan data hasil pengujian, maka dapat diambil beberapa kesimpulan sebagai berikut : 1) Temperatur yang optimal yang digunakan dalam proses pengolahan pisang sale untuk menghasilkan mutu dan kualitas yang lebih baik adalah $90-70^{\circ} \mathrm{C}$ selama 14 jam dengan menggunakan bahan bakar gas elpiji, 2) Semakin tinggi temperatur pada proses pemanasan awal semakin cepat penurunan kadar air dalam proses pengeringan, 3) Hasil penelitian menunjukan bahwa temperatur dan luas penampang bahan yang dikeringkan mempengaruhi kualitas produk dan lamanya pengeringan. Adapun saran dari penelitian ini adalah Penelitian ini masih tahap awal dan perlu dikembangkan lebih lanjut sistem pengolahan pisang sale dan penggunaan bahan bakar nya.

\section{Daftar Rujukan}

Dinas Perkebunan, 2012. Statistik Perkebunan Rakyat. Nanggroe Aceh Darussalam, Banda Aceh.

Ahmad Syuhada, 2002, Pengering ikan dengan menggunakan bahan bakar gas sebagai sumber energi panas untuk pengering, prosiding seminar nasional energi dan management.

Muhammad Thaib hasan, Ahmad Syuhada, Hamdani, Kaji ekperimental karateristik pengering ikan pada alat pengering berbahan bakar gas.Jurnal Teknik Mesin Unsyiah Volume 1 Nomor 2 ( Desember 2012).

Taib, et, al, 1988. Operasi Pengeringan pada pengolahan Hasil Pertanian. PT. Mediyatama Sarana Pererkasa, Jakarta.

Winarno, F.G., 1993. Pengantar Teknologi Bahan Pangan. PT. Gramedia, Jakarta. 